\title{
Higher education in the EU countries: comparative geographical analysis
}

\author{
Marina Voronina ${ }^{1 *}$ \\ ${ }^{1}$ Far Eastern Federal University, 692524 Ussuriysk, Russia.
}

\begin{abstract}
The article analyzes indicators of higher education in the European Union: the number of higher education institutions; the number of university students; changes in the number of faculty members, age structure; higher education expenses; cost of training one student. A similar study was conducted by the author in 2006. The article provides a comparative analysis of indicators for 2001-2016. The analysis uses data from EUROSTAT which were interpreted at the cross-country level.
\end{abstract}

\section{Introduction}

Improvement of the system of higher education is one of the priorities of the European Union.

Article 149 of the Treaty establishing the European Union sets out main provisions of the EU education policy: improvement of the quality of education; educational cooperation; exchange of experience and development of abroad education opportunities; implementation of innovative technologies; creation of a network of academic and professional experts, etc.

\section{Materials and methods}

Some aspects of higher education of the European countries were analyzed by the author in 2006 [1]. This analysis may be of interest to researchers studying the spatial organization of the European higher education.

The study is based on the analysis of statistical data published annually on the official website of the EU. To interpret the indicators, elements of the phased multicriteria analysis of the EUROSTAT data set were used in accordance with the chronology of the EU enlargement.

For a comparative geographical analysis, the following indicators were used:

- the number of higher educational institutions;

- the number of students;
- the dynamics of the faculty structure and age structure;

- cost of higher education;

- expenses per one student.

\section{Results}

History of higher education in Europe dates back to the $\mathrm{XI}-\mathrm{XII}$ centuries, when the first universities appeared in a number of European countries. As a rule, they had only one profile, narrow specializations. For example, universities in Salerno (Italy), Montpellier (France) teach medicine; the University of Bologna was known as a center of jurisprudence; in Paris, there was the best school of theology [2, p. 389].

Currently, in the EU countries, there are thousands of universities. Their distribution is uneven at the intercountry level. Figure 1 presents the graduation of EU countries by the number of universities. Four colors indicate a diversity of countries in the number of universities.

The leaders (more than 200 higher education institutions) are Germany, France, Italy, Poland. The largest group has 11-100 higher education institutions (countries of Northern and Eastern Europe, Spain, Ireland, Malta, Cyprus). Luxembourg is an outsider. It lacks universities, and students study in France, Germany and other EU countries.

\footnotetext{
* Corresponding author: voronina 2003@mail.ru
} 


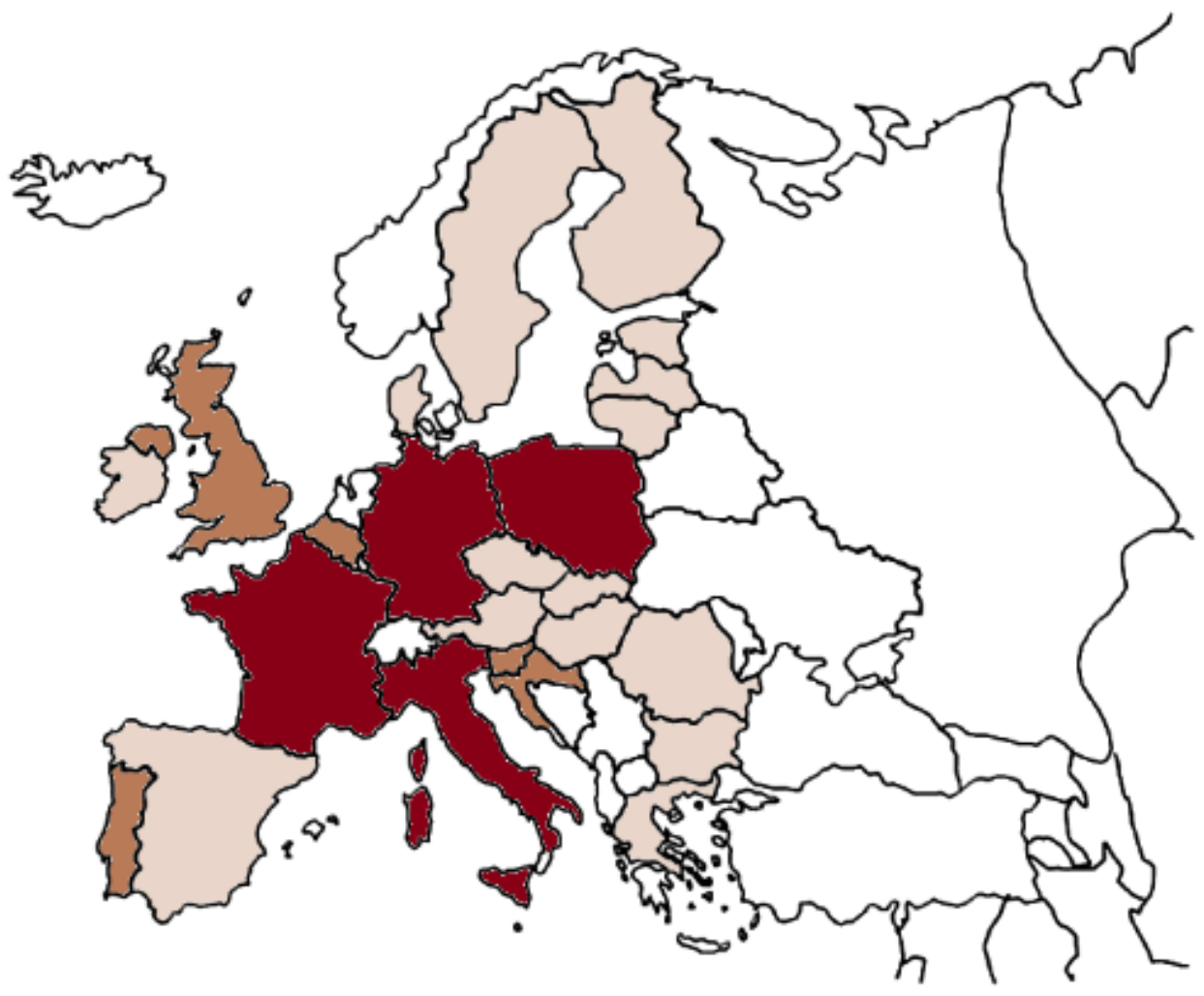

Higher Education Institutions:
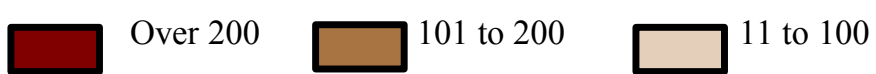

$\square$ Fewer than $10(\mathrm{LU})$

Fig. 1. Location of higher education institutions in the EU countries (based on [3])

There are a lot of students in the EU countries. In 2001 , in 15 EU countries, there were about 12.8 million students, or $3.4 \%$ of the total population of the (Table 1 ). There were significant inter-country differences - from
$4.5 \%$ in Spain to $0.6 \%$ in Luxembourg. In 2015, the student population of 28 EU countries increased to 19.5 million (3.8\% of the total population).

Table 1. Number of students in the European Union in 2001 and 2015 (calculated by $[3,4]$ )

\begin{tabular}{|l|c|r|r|r|c|}
\hline \multicolumn{1}{|c|}{ Country } & $\begin{array}{c}\text { Number of } \\
\text { students, } \\
\text { thousand in } \\
2001\end{array}$ & $\begin{array}{c}\text { \% of the } \\
\text { population }\end{array}$ & $\begin{array}{c}\text { Number of } \\
\text { students, thousand } \\
\text { in 2015 }\end{array}$ & $\begin{array}{c}\text { \% of the } \\
\text { population }\end{array}$ & Growth, \% \\
\hline Belgium & 359.3 & 3.5 & 504.7 & 4.5 & 40.5 \\
\hline Denmark & 190.8 & 3.5 & 2977.8 & 3.7 & 64.5 \\
\hline Germany & 2083.9 & 2.5 & 677.4 & 6.2 & 42.9 \\
\hline Greece & 478.2 & 4.4 & 1963.9 & 4.2 & 7.6 \\
\hline Spain & 1833.5 & 4.5 & 2424.2 & 3.6 & 19.3 \\
\hline France & 2031.7 & 3.4 & 214.6 & 4.6 & 28.8 \\
\hline Ireland & 166.6 & 4.3 & 1776.2 & 2.9 & 1.99 \\
\hline Italy & 1812.3 & 3.1 & 6.9 & 1.2 & 176 \\
\hline Luxembourg & 2.5 & 0.6 & 342.6 & 5.0 & 67.2 \\
\hline Netherlands & 504.0 & 3.1 & 337.5 & 3.2 & 12.9 \\
\hline Portugal & 387.7 & 3.8 & 302.5 & 5.5 & 8.2 \\
\hline Finland & 279.6 & 5.4 & 428.6 & 4.4 & 19.7 \\
\hline Sweden & 358.0 & 4.0 & 2330.3 & 3.6 & 12.7 \\
\hline Great Britain & 2067.3 & 3.4 & 425.9 & 5.0 & 60.9 \\
\hline Austria & 264.7 & 3.3 & 395.5 & 3.7 & \\
\hline Czech & & & 55.2 & 4.2 & \\
\hline Estonia & & & & & \\
\hline
\end{tabular}




\begin{tabular}{|l|r|r|r|r|l|}
\hline Cyprus & & & 37.2 & 4.4 & \\
\hline Latvia & & & 85.9 & 4.3 & \\
\hline Lithuania & & & 140.6 & 4.8 & \\
\hline Hungary & & & 307.7 & 3.1 & \\
\hline Malta & & & 13.2 & 3.0 & \\
\hline Poland & & & 1.665 .3 & 4.4 & \\
\hline Slovenia & & & 85.6 & 4.1 & \\
\hline Slovakia & & & 184.4 & 3.4 & \\
\hline Romania & & & 541.7 & 2.7 & \\
\hline Bulgaria & & & 278.9 & 3.9 & \\
\hline Croatia & & 162.0 & 3.8 & \\
\hline Total, EU-15 & $\mathbf{1 2 . 8}$ & $\mathbf{3 . 4}$ & $\mathbf{1 9 4 8 0 , 2}$ & $\mathbf{3 . 8}$ & \\
& & & & & \\
\hline
\end{tabular}

The data make it possible to identify two groups of countries:

- countries where the share of students in the total number of population exceeds the EU average (Greece, Denmark, Finland, the Netherlands, Austria);

- countries where this indicator is below the EU average (Luxembourg, Romania, Italy).

Indicators of Bulgaria, Croatia, Czech Republic, Germany, France, and Great Britain correspond to the average one.
Comparison of 2001 and 2015 data shows a particularly high increase in students in Luxembourg $(176 \%)$, the Netherlands (67.2\%) and Denmark (64.5\%). In Italy, on the contrary, a growth was minimal - about $2 \%$ for 15 years.

Analysis of EUROSTAT data on the changes in the share of the teaching staff in 2000-2016 indicates heterogeneity of the situation (Fig. 2)

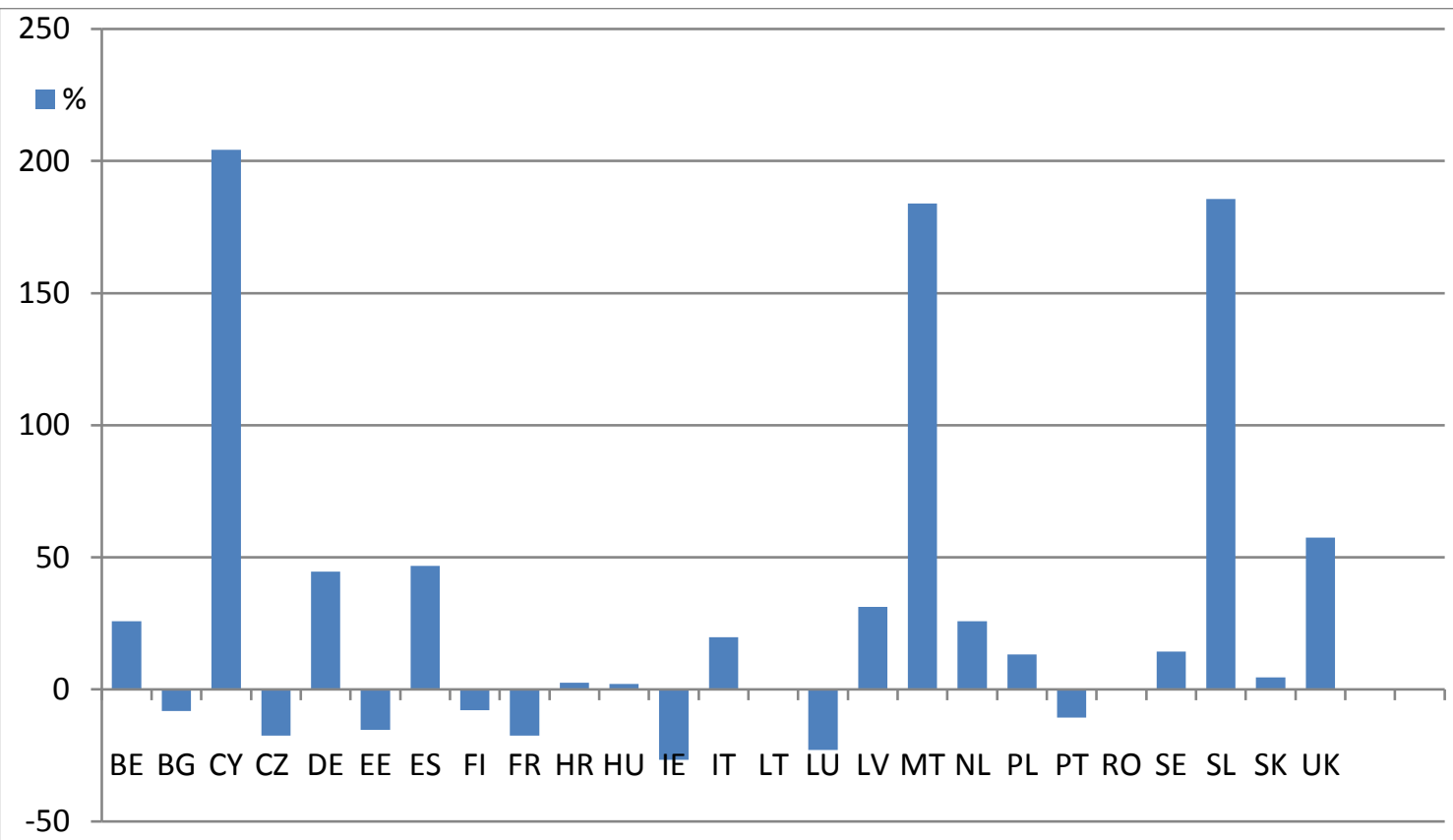

Fig. 2. Changes in the share of faculty members in the EU countries (calculated based on [3])

The maximum growth rates (over 200\%) in Cyprus, Malta and Slovenia are of interest. At the same time, in Bulgaria, the Czech Republic, Estonia, Finland and Romania, the number of university staff decreased. The same situation was typical of France, Ireland and Luxembourg in 2010-2016.

The age structure of the faculty is presented in Figure 3. At the inter-country level, the situation is as follows.
The share of the age group " $35-49$ years old" is the highest; in some countries it accounts for one-third to one-half (Cyprus, France, Portugal) of employees. The share of younger teachers was observed in Luxembourg (54.6\%) and Germany (43.4\%). The age group "65 years and older" has a minimum share in all the EU countries. However, it exceeded the $10 \%$ threshold in Latvia, Italy, Bulgaria, Estonia - countries where the "demographic aging" has affected the area of higher education. 


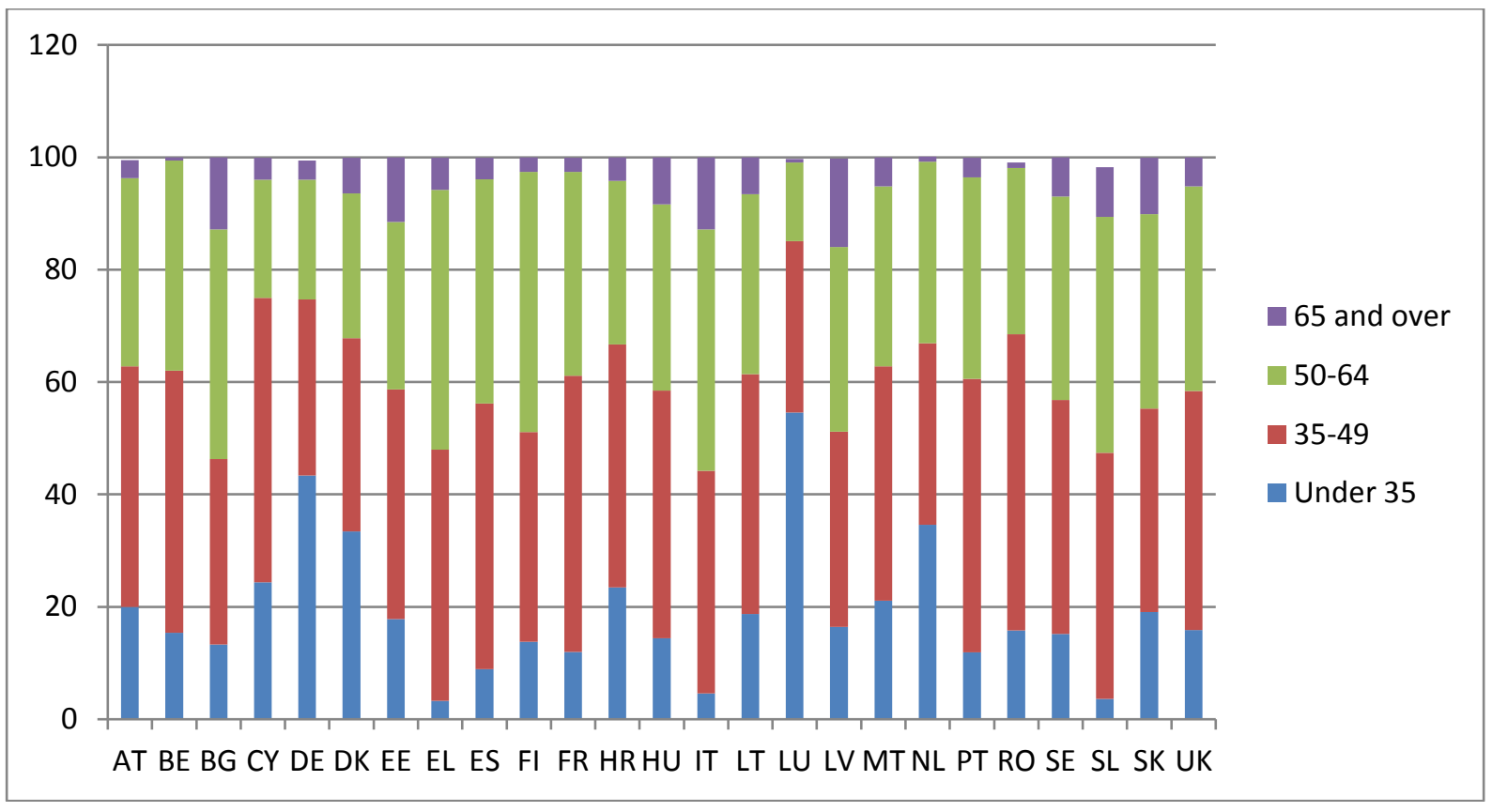

Fig. 3. Age of the EU faculty staff (based on [3])

Expenses on higher education. Universities are financed by governments. The most important indicator that reflects the attitude of the government to its universities is budget expenditures on higher education as a share of GDP. The situation is not homogenous in the European Union.
The expenditures of Luxembourg are the smallest $(0.5 \%)$. Denmark surpasses it 4.6 times. (Denmark has been a leader for 15 years). In Finland and Sweden, the expenditures are high (about 2\%). The group of outsiders includes Romania, Bulgaria, Hungary, Italy, and the Czech Republic (0.7-0.8\%)

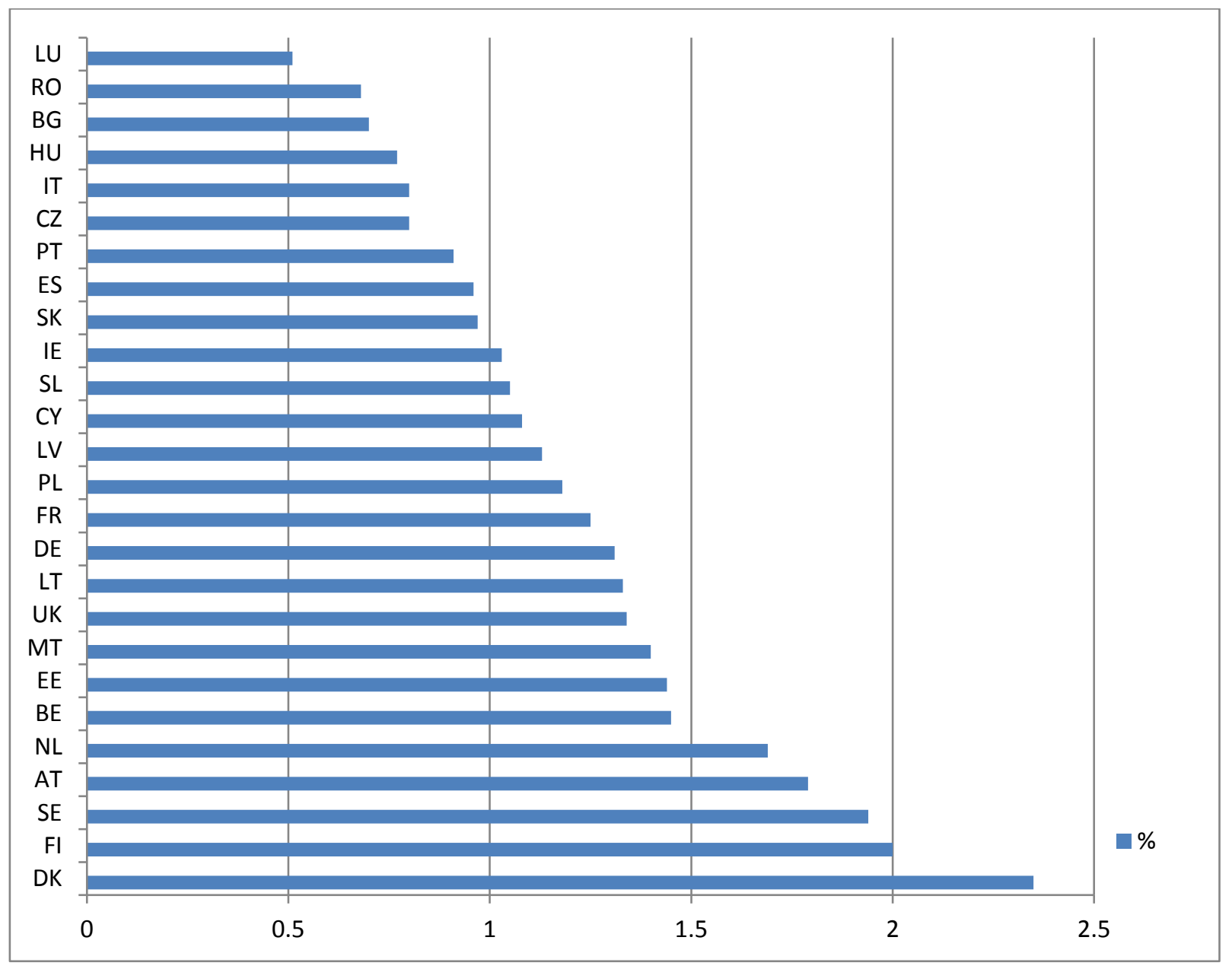


Fig. 4. Expenditures on higher education (\% of GDP) in the European Union, 2014 (based on [3])

The annual cost per student is an important indicator. It indicates how much it costs to train one student. If in 2000 , these costs amounted to over 8,000 ECU, in 2014, they increased to 10398 euros. Differences between countries are significant.

Firstly, in some countries, annual costs are much higher than the average ones: Luxembourg (40,777 euros), Sweden (26,975 euros), Denmark (21,273 euros), etc.

Secondly, in some countries, this indicator approximately corresponds to the median (France, Malta, Ireland).

Finally, in some countries, these costs are below the average ones (Bulgaria, Romania, Hungary, Czech Republic, Poland).

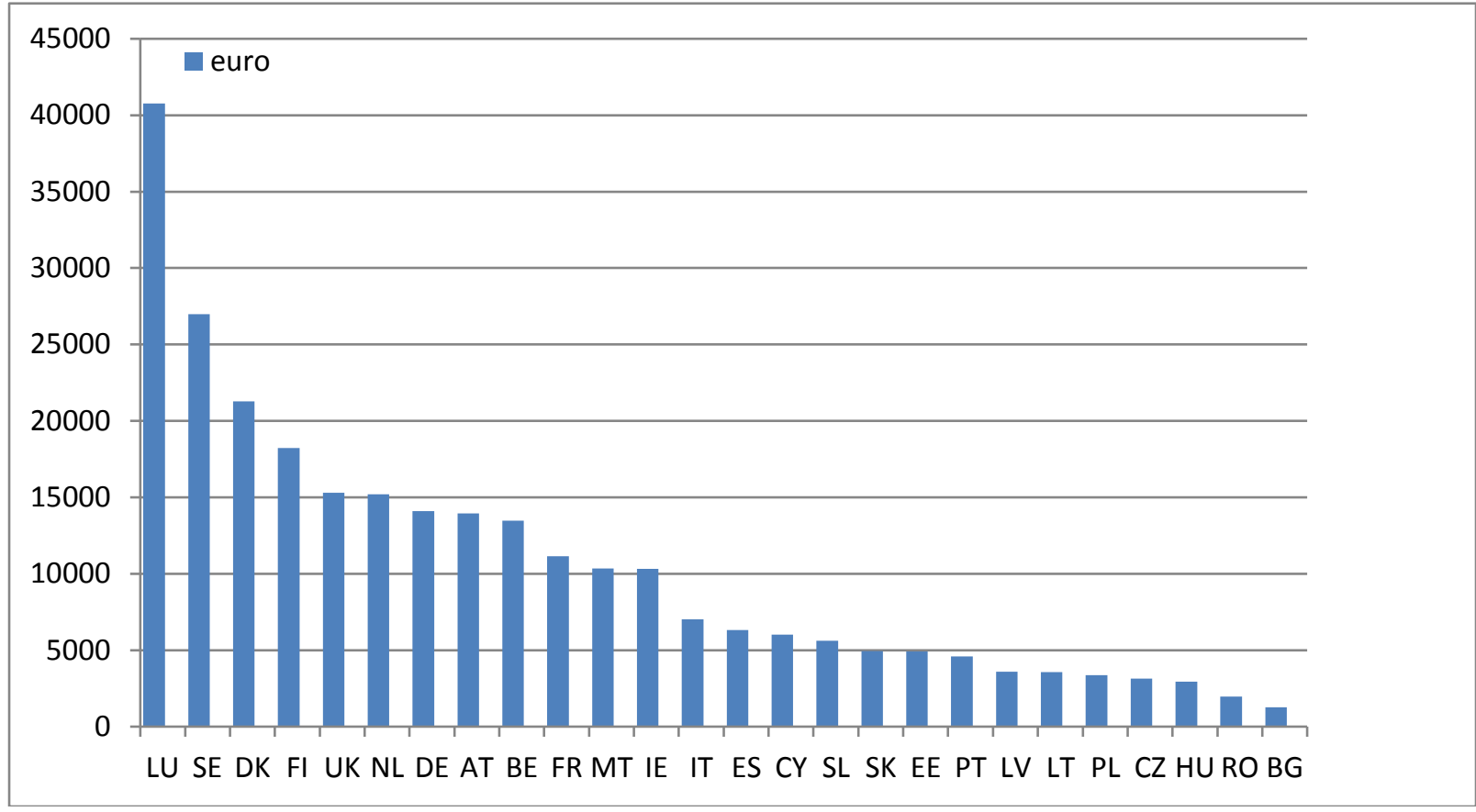

Fig. 5. Costs per student in EU countries, 2014 (based on [3])

\section{Discussion}

Implementation of the EU higher education policy provides for a number of programs that have a global significance. The most famous one is the Erasmus+ which covers the areas of education, vocational training, youth volunteering, etc. 28 countries of the European Union, Turkey, Macedonia, Norway, Iceland and Liechtenstein are involved in this program. In 2017, the program budget amounted to about 2.6 billion euros, of which 881.5 million euros were spent on higher education [5]. The Horizon 2020 program aimed at financial support for research and innovation deals with modernization of higher education.

\section{Conclusion}

In the context of the Bologna process, higher education is one of the priorities of the European social model. Its development is characterized by heterogeneity.

1. The EU countries differ in the number of students. They account for 19.5 million, or $3.8 \%$ of the total EU population. The absolute number of students was recorded in Germany, France and the United Kingdom ( $40 \%$ of the EU students).
2. The number of universities reflects a diversity of EU countries; "more than 200 universities", "101-200", "11-100" and "less than 10".

3. In half of the EU countries, there is an increase in the number of faculty members which is not correlated with the change in the number of students. The average age of staff is " $35-49$ years", although in some countries the share of older teachers is quite high.

4. Universities are funded from public sources. High expenditures on higher education were recorded in Denmark, Finland, and Sweden.

5. Costs per student increased compared with 2000. They are the highest in the above countries. The minimum costs were recorded in Eastern Europe.

\section{References}

1. M.A. Voronina Some features of European higher education (statistical geographical perspective): Komsomol-on-Amur State Pedagogical University, 31-35, (2006)

2. European integration, Business literature. 720 p. (2011).

3. The European Higher Education Area in 2018: Bologna Process Implementation Report. Luxembourg: Publications Office of the European Union, 332, (2018) 
4. Eurostat - Tables, Graphs and Maps Interface (TGM) table

5. Population on 1 January - persons, Retrieved from: https://ec.europa.eu/eurostat/tgm/table.do?tab=table \&language $=$ en $\&$ pcode $=\operatorname{tps} 00001 \&$ tableSelection $=1$ $\underline{\text { \&footnotes }=y e s \& l a b e l i n g=l a b e l s \& p l u g i n}=1$ (2018)

6. Erasmus+ Annual Report 2017 - Statistical Annex. Luxembourg: Publications Office of the European Union, , 104, (2018) 